\title{
Investigating Factors that Influence Employees’ Turnover Intention: A Review of Existing Empirical Works
}

\author{
Ali Hussein Alkahtani ${ }^{1}$ \\ ${ }^{1}$ King Abdul Aziz University, Jeddah, Saudi Arabia \\ Correspondence: Ali Hussein Alkahtani, King Abdul Aziz University, P.O. Box 80201, Jeddah, 21589 Saudi \\ Arabia. E-mail: ealkahtani@kan.edu.sa
}

Received: September 6, 2015

Accepted: October 21, $2015 \quad$ Online Published: November 25, 2015

doi:10.5539/ijbm.v10n12p152

URL: http://dx.doi.org/10.5539/ijbm.v10n12p152

\begin{abstract}
Why employees leave their organizations or companies has been a topic of interest to both researchers and managers. There is no doubt that turnover is costly; thus, it is important to understand what leads to such a phenomenon. Is it job satisfaction? Is it the lack of organizational commitment? Is it the lack of training? Is it the employees' perceived support of both the supervisor/manager and the organization as a whole? Is it organizational climate? Is it organizational justice? This conceptual paper sheds some light on the relevant literature and identifies the antecedents of employees' turnover. The paper proposes a theoretical framework that shows the variables that explain the phenomenon of turnover intention.
\end{abstract}

Keywords: intention to leave, turnover theoretical framework

\section{Introduction}

\subsection{Turnover Intention}

Retention and staff turnover are two important issues that affect organizations in several ways. In this context, it is important to cite Andrew Carnegie, the famous industrialist of the 19th century, who mentioned: "Take away my factories, my plants; take away my railroads, my ships, my transportation, take away my money; strip me of all of these but leave me my key employees, and in two or three years, I will have them all again" (Gupta \& Srivastava, 2007). Moreover, the research of Ahlrichs (2000) highlighted the most underestimated costs of turnover of key employees for employers. There are two kinds of costs for turnover, which are visible and invisible costs.

Visible turnover costs include leave capitalization, recruitment costs, reference checks, security clearance, temporary worker costs, relocation costs, formal training costs and induction expenses. Invisible costs involve enlarged HR and payroll administration, loss of productivity, and informal training. Other hidden costs comprise missed deadlines, loss of organizational knowledge, low motivation as a result of overwork, loss of clients and chain reaction turnover. Another turnover consequence for the organization is its impact on employee-customer relationships. Normally, long-tenured employees develop personal relationships with customers. These relationships are the basis for a re-enforcing cycle of beneficial interactions between employees and customers. Staff retention thus has a positive effect on good customer relationship and ultimately profitability (Rust, Stewart, Miller, \& Pielack, 1996).

Another result of staff turnover is on those who remain with the company. Losing good employees is also costly in terms of the impact it has on company morale. Those that remain may often feel demotivated or disheartened, ensuing in a reduction in productivity and job satisfaction. If other employees observe the new job opportunities being grasped by their colleagues, they could also follow suit. These latter costs, although more difficult to calculate, are also harmful (Hay, 2002).

This paper aims at proposing a conceptual framework that highlights the main antecedents of turnover intention as highlighted in the literature.

There are a number of reasons why turnover takes place. These reasons may range from external environmental variables such as economy that affects the business that in turn shapes the employment levels (Mobley, 1982; Pettman, 1975; Schervish, 1983; Terborg \& Lee, 1984) to organizational factors including types of industry, types of occupation, size of organization, payment, supervisory levels, locations, selection processes, work 
environment, work assignments, benefits, and promotions (Arthur \& Rousseau, 2001; Mobley, 1982).

The other variables that affect employee turnover in organizations involve the individual's work variables such as demographic variables, integrative variables like job satisfaction, pay, promotion and working condition (Arthur, 2001; Mobley, 1982; Pettman, 1975) and the individual's non-working factors such as family related factors (Mobley, 1982; Pettman, 1975).

In addition, demographic variables cannot be disregarded. Age, tenure, level of education, level of income, job category, and gender have been proven to affect employee retention and have been discovered to have established relationship with turnover intention. Among the above demographic factors, age, tenure and income level were discovered to be negatively associated with turnover intention (Arnold \& Feldman, 1982; Cotton \& Tuttle, 1986; Gerhart, 1990; Price \& Mueller, 1986; Tai \& Robinson, 1998; Weil \& Kimball, 1995), level of education is positively related to turnover as employees with higher education levels have higher tendency to quit (Berg, 1991; Cotton \& Tuttle, 1996). With regard to job category, Tai and Robinson (1998) and Price and Mueller (1986) found that non-managerial employees have higher tendency to quit than managerial employees.

Some HRM practices have been recommended as potential answers for turnover problem, such as investment in training, providing organizational support, implementing innovative recruitment and selection processes, providing better career opportunities (Cheng \& Brown, 1998; Forrier \& Sels, 2003; Hinkin \& Tracey, 2000; Walsh \& Taylor, 2007; Walters \& Raybould, 2007) and implementing effective strategies to improve job satisfaction and commitment (Aksu, 2004).

Employee turnover is not only a significant tangible cost but also an intangible or "hidden" cost associated with loss of skills, inefficiency and replacement costs (Lashley \& Chaplain, 1999). Lashley (2000) mentioned that loss of investment in training and loss of staff expertise are examples of turnover costs and opportunity costs. Some authors highlighted more intangible costs of turnover associated with organizational behavior and related "hygiene factors", for example, work reutilization, role conflict, reduced job satisfaction, low morale, reduced commitment, destructive supervision/leadership and a lack of career growth that influence employee productivity, effectiveness, quality and hotel service standards (Deery, Iverson, \& Ervin, 1994; Davidson, Manning, Brosnan, \& Timo, 2001; Davidson, Manning, Brosnan, \& Timo, 2001; Davidson, Manning, Timo, \& Ryder, 2001; O’Connell \& Kung, 2007).

Studies have shown that loss of productivity caused by employee turnover accounts for more than two-thirds of the total turnover costs (Tracey \& Hinkin, 2008). As turnover escalates, service quality deteriorates as it takes time to replace departing employees, especially at busy hotels (Lynn, 2002).

Turnover is harmful for various industries. For example, in the hotel industry, a decline in employee turnover would be a significant factor in lowering costs and enhancing labour productivity. However, managing and accounting for turnover remain a difficult challenge for hotels as there is no single point of accountability within or between units. There seems to be a number of effective strategies to achieve better employee turnover rate and the hotel accountability configuration remains comparatively fragile. The HRM budget generally includes direct costs of turnover (Davidson, Guiding, \& Timo, 2006). This is most probably because the cost of employee turnover is excluded from the conventional accounting practices within hotels. This practice denotes the loss of accountability and poor internal organizational visibility for this cost. The loss of accountability issue is intensified when it is recognized that the cost originates from a different accountability unit (i.e. the area of the organization where the employee works) to the unit that incurs much of the cost associated with employee turnover (HRM).

\subsection{Organizational Commitment}

Mowday, Porter and Steers (1982) defined organizational commitment as a strong belief in and acceptance of the organization's goals and values; a willingness to exert considerable effort on behalf of the organization; and a strong desire to maintain membership in the organization.

Organizational commitment reflects an individual's feelings about the organization as a whole. Organizational commitment has become more crucial than ever in comprehending employee behaviour because it is recognized as more consistent and less dependable on daily variation compared to job satisfaction (Angle \& Perry, 1983; Mowday, et al., 1982). Organizational commitment can be broadly defined as the relative strength of an individual's identification with, and involvement in, an organization (Mowday, Steers, \& Porter, 1979; Meyer, Stanley, Herscovitch, \& Topolnytsky, 2002). As an antecedent, it is understood that committed employees are unlikely to leave the organization, as well as feel the need to go beyond normal job requirements. Committed employees are also willing to make a more significant and personal contribution to the organization, perform 
better, engage in organizational citizenship behaviours (OCBs) and are unlikely to engage in unproductive or destructive behaviours (Iqbal, Aziz, \& Tasawar, 2012; Meyer, Allen, \& Smith, 1993; Meyer, et al., 2002). As an outcome, organizational commitment has been discovered to arise from positive work experiences, job satisfaction, trust in management, and attractive remuneration and rewards (Meyer, et al., 2002).

Studies in this area have reported a strong relationship between organizational commitment and turnover, signifying that higher levels of commitment will result in lower levels of intention to leave, therefore lower turnover (Allen \& Meyer, 1990; Bentein, Vandenberghe, Vandenberg, Stinglhamber, 2005; Falkenburg \& Schyns, 2007; Good, Page, \& Young, 1996; Harris \& Cameron, 2005; Huselid, 1995; Rhoades \& Eisenberger, 2002). Organizational commitment is one of the predictors of turnover intention (Arnold \& Feldman, 1982; Hollenbeck \& Williams, 1986). Qi (2007) found that affective commitment has a significant negative influence on turnover intention, which is similar to a research done by Law (2005), which showed that affective commitment is the most important component of commitment in predicting employees' turnover.

\subsection{Job Satisfaction}

Many studies have indicated that job satisfaction serves as an antecedent to turnover intention. For example, Ali (2008) highlighted that problems might arise if employees' dissatisfaction are not taken into consideration. Employees who are dissatisfied would sooner or later leave the organization, and at the same time, the organization loses the knowledge that the employees had brought in. If the organization decided to employ new employees to replace those who leave, and their feelings of dissatisfaction are not met, this could affect the daily operation of the organization, and the vicious cycle of turnover will occur. In addition, Hay (2002) discovered that the majority of the employees chose career opportunities, and learning and development as the foremost reasons to stay in an organization, which lead to job satisfaction.

Career satisfaction and career success are interchangeably used in this study. Career success is defined as positive psychological or work-related outcomes or achievements that a person gathers as the outcome of work experiences (Judge, Higgins, Thoresen, \& Barrick, 1999). Models of career success have incorporated a number of demographic, human capital, and motivational variables related to career success (Judge, Cable, Boudreau, \& Bretz Jr, 1994; Judge, et al., 1999). Previously, much research on careers have viewed the individual as being passive and influenced by situational factors (Bell \& Staw, 1989). Career/job satisfaction is a significant predictor of employee turnover (Egan, Yang, \& Bartlett, 2004; Wright \& Bonett, 2007). Employees most probably leave their organization when both their psychological well-being and job satisfaction are low (Wright $\&$ Bonett, 2007). Satisfaction with meaningful work and promotion opportunities were significant predictors of turnover intention (Wright \& Bonett, 1992).

Previous studies have discovered that job dissatisfaction is associated with negative behavioural outcomes such as absenteeism, workplace accidents, and labour turnover (Griffeth, Hom, \& Gaertner, 2000; Newstrom, 2007; Sousa-Poza \& Sousa-Poza, 2007). Currall, Towler, Judge, and Kohn (2005) discovered that pay satisfaction is positively related to performance and negatively related to employee turnover intention. Similarly, the outcome of another study by Davis (2006) also showed that general job satisfaction is strongly and negatively associated with turnover intention. Job satisfaction has been empirically proven to be the main predictor of turnover intention (Larrabee, Janney, Ostrow, Withrow, Hobbs, \& Burant, 2003; Parry, 2008).

\subsection{Training}

Some scholars have agreed that there is a positive connection between the staff turnover rate and the scale of investment in training in two ways (Green, Machin, \& Wilkinson, 1996). The first interpretation contends that organizations with high turnover will invest more in training so as to replace the skills and competencies of the outgoing personnel (replacement investments) and/or to increase employment loyalty in the future (retention management). The second interpretation claims that organizations train extensively thereby generating higher turnover precisely because the trained employees leave the organization for better paid jobs where they can use the skills they have acquired. Training increases the value of the employees, and this increases the probability of being picked by rival organizations.

Some groups of scholars in the field of economics claim a negative relationship between turnover and training. It is influenced by Becker's Human Capital Theory. Becker (2009) asserted that the investment in training is the outcome of optimising decisions agreed by both workers and employers. The improved skills resulting from general training enable workers to extract higher wages from their current or future employers. Since employers are confronted with the risk of not being able to recover this investment, they will not be willing to support general training of their workers. Firm-specific training, on the other hand, cannot generate an increased wage with other than the current employers. Therefore, firms can recover their investment in specific training and they 
will be willing to share some or all of the costs of specific training. According to Becker (2009), a purely competitive labour market will always provide the optimal level of training investment.

\subsection{Perceived Organizational Support}

Perceived Organizational Support (POS) reflects the overall belief of employees that their organization values their contribution and cares about their well-being (Eisenberger, Huntington, Hutchison, \& Sowa, 1986). The concepts of social exchange and the norm of reciprocity are often used by researchers to describe the motivation for employees to display positive behaviours towards their organization, such as loyalty, which are not formally rewarded or contractually required by the organization (Rhoades \& Eisenberger, 2002; Settoon, Bennett, \& Liden, 1996).

However, the relationship between POS and turnover intention appears to clarify options for managers to take positive steps to retain valuable employees.

Loi, Hang-Yue, and Foley (2006) have put an effort to measure the mediating role of POS on the relationship between perceived justice, predicting organizational commitment and intention to leave, while controlling for the effects of the size of the firm and demographic variables. They found that POS mediated the relationship between organizational justice (procedural and distributive) and both organizational commitment and intention to leave. Although the association between organizational commitment and turnover intention has been well established, research into the relationship between POS and turnover intention has only been given serious attention recently (Rhoades \& Eisenberger, 2002; Stinglhamber \& Vandenberghe, 2003).

Eisenberger et al. (1986) proposed that in order to assess the willingness of the organization to reward employees' efforts, they generate perceptions as to the extent to which the organization cares about their well-being and values their contribution, which they label as perceived organizational support (POS).

The provision of organizational support to an employee is likely to create feelings of goodwill towards the organization, strengthening the bond between employer and employee, which, in turn, increases the feelings of obligation to repay the organization, through the norm of reciprocity (Eisenberger, Fasolo, \& Davis-LaMastro, 1990; Maertz, Griffeth, Campbell, \& Allen, 2007).

As a result, POS should be positively related to affective organizational commitment and negatively related to turnover intentions. Recent studies confirm these relationships empirically in the Western settings (Wayne, Shore, \& Liden, 1997; Rhoades, Eisenberger, \& Armeli, 2001; Rhoades \& Eisenberger, 2002; Maertz et al., 2007).

\subsection{Perceived Supervisor Support}

A review of existing studies suggests that when employees develop general views concerning the degree to which their supervisors care about their well-being and value their contributions towards the organization, it is called Perceived Supervisor Support or PSS (Maertz et al., 2007). PSS has received increasing attention in the literature and has been discovered to be significantly related to important organizational outcomes including employee turnover and turnover intentions (Rhoades \& Eisenberger, 2002; Maertz et al., 2007).

Studies were primarily conducted in the Western settings and the findings confirm the existence of a strong positive relationship between perceived work-related support and organizational outcomes such as organizational commitment, turnover intentions and turnover behaviour (Rhoades et al., 2001; Rhoades \& Eisenberger, 2002; Rhoades \& Eisenberger, 2002). Existing studies have reported significant positive relationship between PSS and POS (Yoon \& Lim, 1999; Yoon \& Thye, 2000; Rhoades et al., 2001; Rhoades \& Eisenberger, 2002). However, there is an argument in the literature about the link between PSS and POS.

A group of scholars suggest that the influence of PSS on organizational outcomes, such as affective commitment and employee turnover intentions, is fully mediated by POS (Rhoades \& Eisenberger, 2002; Rhoades et al., 2001). Rhoades and Eisenberger (2002) discovered that POS fully mediate the relationship between PSS and turnover. Rhoades et al. (2001) supported their view by highlighting that the influence of PSS on affective commitment was fully mediated through PSS. Another group of scholars suggest that supervisor level constructs such as PSS might have direct as well as indirect influences on organizational outcomes such as turnover intentions (Becker, 2009; Maertz et al., 2007; Maertz, Mosley, \& Alford, 2002).

The relationship between POS and a number of outcome variables has been established and particular attention has been given to POS in the context of employee turnover. Indeed, many supportive organizational practices are specifically intended to increase the connection between employee and employer in order to reduce voluntary turnover. Participation in decision-making, fairness of rewards (Allen, Shore, \& Griffeth, 2003), developmental experiences and promotions (Wayne, Shore, \& Liden, 1997), autonomy (Aubé, Rousseau, \& Morin, 2007), and 
job security (Rhoades \& Eisenberger, 2002) have been empirically associated with POS. These actions reflect the organization's inclination to meet employees' socio-emotional needs (Eisenberger et al., 1986). POS ensures employees that the organization stands behind them as they perform their jobs and cope with stressful situations (George, Reed, Ballard, Colin, \& Fielding, 1993). In agreement with the norm of reciprocity, supported employees tend to value and respect their organization and are therefore willing to contribute to the organization's goals.

Foong-ming (2008) mentioned that supervisors mainly participated in performance evaluation and feedback. Hence, the supervisors' favorable or unfavorable action mirrors an organization's view and decisions on employees. Referring to a study conducted by Gentry, Kuhnert, Mondore, and Page (2006), employees who are given a voice, open communication, recognition, supported by their respective supervisors, and have their well-being cared for, are inclined to stay with the organization for a long period of time.

\subsection{Organizational Climate}

Most of the employees remain with the organization if they receive motivating tools such as bonuses but yet remuneration is not the only thing that can motivate employees to remain with the organization (Anderfuhren-Biget, Varone, Giauque, \& Ritz, 2010; Masaiti \& Naluyele, 2011). The biggest factor in attracting and most importantly retaining key employee is culture. It is important for employees to feel like they are part of a team, they require a link to the vision and direction of the organization and their co-employees, and they require ways of working better together, which ultimately lead to more cooperation.

Recent research (Schyns, van Veldhoven, \& Wood, 2009; Rashid, Wineman, \& Zimring, 2009; Khan, Hassan, Anwar, Babar, Babar, \& Khan, 2007) established that discouraging organizational climate negatively affects job satisfaction which in turn may expedite employee turnover.

Moran and Volkwein (1992), for example, defined corporate climate as a relatively stable characteristic of an organization which differentiate it from other organizations and; (a) represents members' shared perceptions about their organization with respect to dimensions such as autonomy, cohesiveness, support, recognition, innovation, and fairness; b) is generated from members' interaction; (c) acts as a basis for interpreting the situation; (d) manifests the prevalent norms, values, and attitudes of organizational cultures; and (e) serves as a source of power for forming behaviour.

Lambert, Hogan, and Barton (2001) highlighted five variables of work environment, namely; role conflict, task variety, financial rewards, relations with co-workers and autonomy/participants. Moreover, Downey, Don, and Slocum (1975) recommended six components of organizational climate; decision making, warmth, risk, openness, reward and structure. Altmann (2000) proposed that corporate climate can be classified into the following dimensions; job, role, leaders, organization and workgroup.

Employees are more likely to leave if they perceive a lack of clear direction from the management. It seems that companies are less proficient at marketing themselves to their employees than they are at selling the company to other stakeholders (Hay, 2002).

Stone, Larson, Mooney-Kane, Smolowitz, Lin, and Dick (2006) established that there is a link between organizational climate and intention to leave. Thatcher, Stepnia, and Boyle (2003) confirmed the effect of organizational climate on the turnover intention in an information technology firm. They discovered a strong relationship between them.

\subsection{Employee Benefits and Opportunities}

Research has established that financial reward is one of the basic types of extrinsic monetary rewards which comprise the basic needs of income to survive (to pay bills), a feeling of stability and consistency (the job is secure), and recognition (my workplace values my skills) (Aguenza \& Som, 2012).

Higginbotham (1997) mentioned that high salaries are not important, but "good" and "fair" salaries indicate a strong correlation with intention to remain, signifying that as long as the compensation is competitive, financial rewards are not the primary factor in retention. Kochanski and Ledford (2001) supported this testimonial, which signify that the actual level of pay is less important than feelings about pay raises and the process used to manage them.

Previous studies investigated how family-friendly practices and work-life balance practices were associated with employee retention (Grover \& Crooker, 1995) and summarized that childbirth and child-rearing are left with the promise of full-time re-employment and retention can be promoted by disseminating information about local childcare services. Many intermediary factors, e.g. job satisfaction, organizational commitment, motivation, trust 
(in the organization), and other job attitude factors, have been accepted with proven effects. In investigating the link between employee benefit programs and retention, another model was examined with regard to the effect of monetary worth (an objective factor) of employee stock options programs and the feeling of participating in company management through this (a subjective factor), which may lead to withdrawal intention and actual spontaneous resignation by way of multi-step awareness, i.e. satisfaction with the system, overall job satisfaction, and organizational commitment (Buchko, 1993). In summary, this model clarify that both the objective and subjective factors are related to retention, and that job satisfaction is important as an intermediary factor.

Gustafson (2002) established in her study that compensation and opportunities for better pay largely lead to employees' turnover intention in organizations. An important theory used as reference in this study is equity theory developed by Adams (1965) that explained that individuals, who value fair treatment, will strive to keep the relationships between members within an organization. And so, if the employees feel that inequality exists in pay treatment, a range of negative behaviors will be present such as absenteeism, and the desire to leave the organization.

\subsection{Organizational Justice}

Organizational justice was first applied by Greenberg in the 1970s (Greenberg, 1987). The author described organizational justice as a fair and equitable behavior of the organizations towards their employees (Rafei-Dehkordi Mohammadi \& Yektayar, 2013).

In order to ensure that employees are satisfied, committed, and loyal, the organization needs to be fair in its systems regarding distributive, procedural, and interactional justice. When employees feel that they are treated fairly by the organization in every aspect, they are likely to show more positive attitude and behaviors such as job satisfaction (Karimi, Alipour, Pour, \& Azizi, 2013) and commitment (Malik \& Naeem, 2011).

A lot of studies have empirically proven that job satisfaction is related to higher levels of organizational justice (Dundar \& Tabancali, 2012; Nojani, Arjmandnia, Afrooz, \& Rajabi, 2012; Taheri \& Soltani, 2013).

Organizational justice can be described as a blend of fairness in procedures used by leaders to decide on outcome distributions or allocations, and the fairness of outcome distributions or allocations (Colquitt, Conlon, Wesson, Porter, \& Ng, 2001).

Organizational justice has been empirically proven to be strongly associated with many dynamics related to change, such as openness to change, acceptance of change, cooperation with change, satisfaction with change (Blader \& Tyler, 2005; Tyler \& Blader, 2003; Wanberg \& Banas, 2000) and individual response to change (Greenberg, 2001). In addition, it has been also considered as an antecedent of commitment to change (Foster, 2010; Kool \& van Dierendonck, 2012; Paolillo, Platania, Magnano, \& Ramaci, 2015). Intention to leave and later turnover action are an essential part of change that managers must be aware of.

Justice is a concept that encompasses many dimensions, which include a range of questions, from compensation that employees get to behavioral treatment towards employees by their superior. The function of fairness related to the place of work is referred to as organizational justice; it includes the ways that decide the fair treatment of employees during the performance of their jobs and as a result this influences employees' behavior at work (Moorman, 1991).

Likewise, Matin, Jandaghi, and Ahmadi (2010) categorized the types of justice as follows; distributive justice is the type of organizational justice that emphasizes on the perceptions of the people that the amount they received fairly refects the outcomes of the value added work. Procedural justice manifests people's beliefs of the fairness of the procedures that determine the outcomes they have. Unfair procedures will lead to the rejection of the entire system (Al-Salemi, 2013; Matin et al., 2010).

Although the organizational justice is a comprehensive term that describes the employees' perceptions of fairness in an organization as a whole, psychologists and social experts classify them into three components; distributive, procedural, and interactional justice (Dessler, 2005).

Distributive justice concerns people's beliefs that they have received a fair amount of valued work-related outcomes (e.g., pay, recognition, etc.) (Greenberg \& Baron, 2008). Distributive justice was discovered to be linked to work outcomes such as pay satisfaction, job satisfaction, organizational commitment and trust in organization (Cohen-Charash \& Spector, 2001). Procedural justice reflects the fairness of the decision process that lead to a particular outcome (Leventhal, Karuza, \& Fry, 1980). Studies have shown that people are likely to accept an unfavorable outcome if they believe that the decision process leading up to it was performed according to organizational justice principles (e.g., consistency, neutrality, accuracy, correctability, etc.) (Baldwin, 2006). 
Organizational justice is a general term used to reflect individuals' perceptions of fairness within organizations and the effect of those perceptions on behavior (Adams, 1965; Clayton \& Opotow, 2003; Colquitt et al., 2001; Folger \& Cropanzano, 1998; Tyler \& Blader, 2003). It can also be described as the employees' perception on the fairness and sincerity of treatment they received (Elovainio, van den Bos, Linna, Kivimäki, Ala-Mursula, Pentti, \& Vahtera, 2005) and the fairness of the process and results obtained at the workplace (Hubbel \& Chory-Assad, 2005).

A review of existing studies indicates the existence of multiple facets of organizational justice; namely, distributive, procedural and interactional justice (Cropanzano, Byrne, Bobocel, \& Rupp, 2001; Konovsky, 2000; Greenberg, 1990). Distributive justice primarily relates to the employee perception about the fairness of outcomes (Greenberg, 1987; 1990) such as financial rewards received from their organization (Greenberg, 2006; Colquitt, Scott, Judge, \& Shaw, 2006; Ramamoorthy \& Flood, 2004; Elovainio, Kivimäki, Steen, \& Vahtera, 2004; Aryee, Budhwar, \& Chen, 2002).

Procedural justice primarily concerns the processes and methods through which outcome decision is reached (Cropanzano \& Greenberg, 1997; Ding \& Lin, 2006; Greenberg, 1990). It is the employees' perception about fairness in the rules and regulations which serve as a basis to make a decision that subsequently lead to the ultimate outcome (Aryee et al., 2002; Byrne, 2005; DeConinck \& Bachmann, 2005; Ding \& Lin, 2006; Elovainio et al., 2004; Greenberg, 2001).

Interactional justice is regarded as the main concern in workplace settings because of its relationship with unfair and fair treatment (Cohen-Charash \& Spector, 2001; Martı'nez-Tur et al., 2006). Later, studies have established the two subcategories of interactional justice known as interpersonal and informational justice and should be considered as separate (Colquitt, 2001). Greenberg (1990) recommended two specific types of interpersonal treatment; (1) informational justice which mainly emphasizes on why the specific outcome of an activity emerges in a certain fashion, and (2) interpersonal justice which concerns how employees are treated with dignity, politeness and respect by others.

Based on the discussion, the following are the research propositions:

P1: Employees' organizational commitment (affective, normative and continuance commitment) reduces employees' turnover intention.

P2: Employees' job satisfaction reduces employees' turnover intention.

P3: Training reduces employees' turnover intention.

P4: Perceived organizational support reduces employees' turnover intention.

P5: Perceived supervisor support reduces employees' turnover intention.

P6: Organizational climate reduces employees' turnover intention.

P7: Employees' benefits and opportunities reduce employees' turnover intention.

P8: Organizational justice (distributive, procedural, and interactional justice) reduces employees' turnover intention.

\section{Conclusion}

\subsection{Managerial Implication}

Employees' turnover has become a critical issue in today's organizations. The rate of employee turnover has been increasing from time to time due to a lot of factors. This review of previous studies is intended to consolidate previous research findings in order to establish a cohesive framework of employee turnover so that organizations are aware of the factors that might lead to turnover. Based on the review, seven common factors are found to be related to turnover; namely, organizational commitment, job satisfaction, training, perceived organizational support, perceived supervisor support, organizational climate, employees' benefits and opportunities and organizational justice. These factors have to be taken care of by the organizations to ensure that they can retain their employees especially those that can contribute significantly to the well-being of the organizations. Employee-organization link is considered as a reciprocal relationship. If the employees feel that they are taken care of by the organization, they will repay in terms of their loyalty to the organization.

\subsection{Suggestions for Future Research}

This paper is meant to establish a framework of employee turnover based on the findings of the previous research works. The proposed relationships have to be empirically tested to examine whether they remain as significant predictors of turnover or otherwise, regardless of the contexts of the study. Some factors might 
remain as predictors and others might act as mediators or moderators for the main relationship, therefore, this relationship must be rigorously tested using the appropriate analyses. Besides, due to the abundance of research instruments available to gauge the levels of employees' turnover and its predictors, future researchers must take precautionary measures to choose the one that is most valid and reliable. In most instances, the influence of extraneous factors is inevitable, therefore, the use of control variables are advisable to ensure that the results are truly reflective of the influence of the main factors that affect the phenomenon of interest. The control variables can be the demographic variables such as age, gender, education level, tenure, job position and others. They can also be in the form of organizational variables such as types of organizations or nature of business.

\section{References}

Adams, J. S. (1965). Inequity in social exchange. Advances in Experimental Social Psychology, 2, 267-299.

Aguenza, B. B., \& Som, A. P. M. (2012). Motivational factors of employee retention and engagement in organizations. International Journal of Advances in Management and Economics, 1(6), 88-95.

Ahlrichs, N. S. (2000). Competing for Talent: Key Recruitment and Retention Strategies for Becoming an Employer of Choice. Davies-Black Publishing.

Aksu, A. A. (2004). Turnover costs: Research among five-star hotels in the city of Antalya, Turkey. Tourism Analysis, 9(3), 207-217.

Ali, N. (2008). Factors affecting overall job satisfaction and turnover intention. Journal of Managerial Science, 2(2), 239-252.

Allen, D. G., Shore, L. M., \& Griffeth, R. W. (2003). The role of perceived organizational support and supportive human resource practices in the turnover process. Journal of Management, 29(1), 99-118. http://dx.doi.org/10.1177/014920630302900107

Allen, N. J., \& Meyer, J. P. (1990). The measurement of antecedents of affective, continuance and normative commitment to the organization. Journal of Occupational Psychology, 63(1), 1-18. http://dx.doi.org/10.1111/j.2044-8325.1990.tb00506.x

Al-Salemi, A. M. A. (2013). The impact of organizational justice on employee turnover, using Total E\&P Yemen. African Journal of Business Management, 7(37), 3810-3826. http://dx.doi.org/10.5897/AJBM12.1424

Altmann, R. (2000). Forecasting your organizational climate. Journal of Property Management, 65(4), 62-67.

Anderfuhren-Biget, S., Varone, F., Giauque, D., \& Ritz, A. (2010). Motivating employees of the public sector: Does public service motivation matter? International Public Management Journal, 13(3), 213-246. http://dx.doi.org/10.1080/10967494.2010.503783

Angle, H. L., \& Perry, J. L. (1983). Organizational commitment individual and organizational influences. Work and Occupations, 10(2), 123-146. http://dx.doi.org/10.1177/0730888483010002001

Arnold, H. J., \& Feldman, D. C. (1982). A multivariate analysis of the determinants of job turnover. Journal of Applied Psychology, 67(3), 350-360. http://dx.doi.org/10.1037/0021-9010.67.3.350

Aryee, S., Budhwar, P. S., \& Chen, Z. X. (2002). Trust as a mediator of the relationship between organizational justice and work outcomes: Test of a social exchange model. Journal of Organizational Behavior, 23(3), 267-285. http://dx.doi.org/10.1002/job.138

Arthur, M. B., \& Rousseau, D. M. (2001). The boundaryless career: A new employment principle for a new organizational era. New York, NY: Oxford University Press.

Aubé, C., Rousseau, V., \& Morin, E. M. (2007). Perceived organizational support and organizational commitment: The moderating effect of locus of control and work autonomy. Journal of Managerial Psychology, 22(5), 479-495. http://dx.doi.org/10.1108/02683940710757209

Baldwin, S. (2006). Organizational justice. UK: Institute for Employment Studies.

Becker, G. S. (2009). Human capital: A theoretical and empirical analysis, with special reference to education. University of Chicago Press.

Bell, N. E., \& Staw, B. M. (1989). People as sculptors versus sculpture: The roles of personality and personal control in organizations. In M. B. Arthur, D. T. Hall, \& B. S. Lawrence (Eds.), Handbook of career theory. New York, NY: Cambridge University Press.

Bentein, K., Vandenberghe, C., Vandenberg, R., \& Stinglhamber, F. (2005). The role of change in the relationship between commitment and turnover: A latent growth modeling approach. Journal of Applied Psychology, 
90(3), 468-482. http://dx.doi.org/10.1037/0021-9010.90.3.468

Berg, T. R. (1991). The importance of equity perception and job satisfaction in predicting employee intent to stay at television stations. Group \& Organization Management, 16(3), 268-284. http://dx.doi.org/10.1177/105960119101600303

Blader, S. L., \& Tyler, T. R. (2005). How can theories of organizational justice explain the effects of fairness? In J. Greenberg \& J. A. Colquitt (Eds.), Handbook of organizational justice (pp. 329-354). Mahwah, NJ: Lawrence Erlbaum Associates.

Buchko, A. A. (1993). The effects of employee ownership on employee attitudes: an integrated causal model and $\begin{array}{lllll}\text { path analysis. Journal of } & \text { Management }\end{array}$ http://dx.doi.org/10.1111/j.1467-6486.1993.tb00319.x

Cheng, A., \& Brown, A. (1998). HRM strategies and labour turnover in the hotel industry: A comparative study of Australia and Singapore. International Journal of Human Resource Management, 9(1), 136-154. http://dx.doi.org/10.1080/095851998341233

Clayton, S., \& Opotow, S. (2003). Justice and identity: Changing perspectives on what is fair. Personality and Social Psychology Review, 7(4), 298-310. http://dx.doi.org/10.1207/S15327957PSPR0704_03

Cohen-Charash, Y., \& Spector, P. E. (2001). The role of justice in organizations: A meta-analysis. Organizational Behavior and Human Decision Processes, 86(2), 278-321. http://dx.doi.org/10.1006/obhd.2001.2958

Colquitt, J. A. (2001). On the dimensionality of organizational justice: A construct validation of a measure. Journal of Applied Psychology, 86(3), 386-400. http://dx.doi.org/10.1037/0021-9010.86.3.386

Colquitt, J. A., Conlon, D. E., Wesson, M. J., Porter, C. O., \& Ng, K. Y. (2001). Justice at the millennium: A meta-analytic review of 25 years of organizational justice research. Journal of Applied Psychology, 86(3), 425-445. http://dx.doi.org/10.1037/0021-9010.86.3.425

Colquitt, J. A., Scott, B. A., Judge, T. A., \& Shaw, J. C. (2006). Justice and personality: Using integrative theories to derive moderators of justice effects. Organizational Behavior and Human Decision Processes, 100(1), 110-127. http://dx.doi.org/10.1016/j.obhdp.2005.09.001

Cotton, J. L., \& Tuttle, J. M. (1986). Employee turnover: A meta-analysis and review with implications for research. Academy of Management Review, 11(1), 55-70. http://dx.doi.org/10.5465/AMR.1986.4282625

Cropanzano, R., Byrne, Z. S., Bobocel, D. R., \& Rupp, D. E. (2001). Moral virtues, fairness heuristics, social entities, and other denizens of organizational justice. Journal of Vocational Behavior, 58(2), 164-209. http://dx.doi.org/10.1006/jvbe.2001.1791

Cropanzano, R., \& Greenberg, J. (1997). Progress in organizational justice: Tunneling through the maze. International Review of Industrial and Organizational Psychology, 12, 317-372.

Currall, S. C., Towler, A. J., Judge T. A., \& Kohn, L. (2005). Pay satisfaction and organizational outcomes. Personnel Psychology, 58(3), 613-640. http://dx.doi.org/10.1111/j.1744-6570.2005.00245.x

Davidson, M., Guilding, C., \& Timo, N. (2006). Employment, flexibility and labour market practices of domestic and $\mathrm{MNC}$ chain luxury hotels in Australia: Where has accountability gone? International Journal of Hospitality Management, 25(2), 193-210. http://dx.doi.org/10.1016/j.jhm.2005.08.001

Davidson, M., Manning, M. L., \& Timo, N. (2001). Are customer satisfaction and performance in hotels influenced by organisational climate? Australian Journal of Hospitality Management, 8(1), 41-54.

Davidson, M., Manning, M. L., Brosnan, P., \& Timo, N. (2001). Organisational climate, perceived customer satisfaction and revenue per available room in four- to five-star Australian hotels. Tourism Analysis, 6(2), 123-137. http://dx.doi.org/10.3727/108354201108749782

Davidson, M., Manning, M., Timo, N. \& Ryder, P. (2001). The dimensions of organisational climate in four- and five-star Australian hotels. Journal of Hospitality and Tourism Research, 25(4), 444-461. http://dx.doi.org/10.1177/109634800102500406

Davis, P. J. (2006). In search of the common wealth: A service-profit chain for the public sector. International Journal of Productivity and Performance Management, 55(2), 163-172. http://dx.doi.org/10.1108/17410400610641735

DeConinck, J., \& Bachmann, D. (2005). An analysis of turnover among retail buyers. Journal of Business Research, 58(7), 874-882. http://dx.doi.org/10.1016/j.jbusres.2003.10.009 
Deery, S. J., Iverson, R. D., \& Erwin, P. J. (1994). Predicting organizational and union commitment: The effect of industrial relations climate. British Journal of Industrial Relations, 32(4), 581-597. http://dx.doi.org/10.1111/j.1467-8543.1994.tb01052.x

Dessler, G., Sutherland, G., \& Cole, N. D. (2005). Human resources management in Canada. Canada: Pearson Education.

Ding, C. G., \& Lin, C. P. (2006). Comparing the effects of determinants of turnover intentions between Taiwanese and US hospital employees. Human Resource Development Quarterly, 17(4), 403-421. http://dx.doi.org/10.1002/hrdq.1183

Downey, H. K., Don, H., \& Slocum, J. W. (1975). Congruence between individual needs, organizational climate, job satisfaction and performance. Academy of Management Journal, 18(1), 149-155. http://dx.doi.org/10.2307/255634

Dundar, T., \& Tabancali, E. (2012). The relationship between organizational justice perceptions and job satisfaction levels. Procedia-Social and Behavioral Sciences, 46, 5777-5781. http://dx.doi.org/10.1016/j.sbspro.2012.06.513

Egan, T. M., Yang, B., \& Bartlett, K. R. (2004). The effects of organizational learning culture and job satisfaction on motivation to transfer learning and turnover intention. Human Resource Development Quarterly, 15(3), 279-301.

Eisenberger, R., Fasolo, P., \& Davis-LaMastro, V. (1990). Perceived organizational support and employee diligence, commitment, and innovation. Journal of Applied Psychology, 75(1), 51-59. http://dx.doi.org/10.1037/0021-9010.75.1.51

Eisenberger, R., Huntington, R., Hutchison, S., \& Sowa, D. (1986). Perceived organizational support. Journal of Applied Psychology, 71(3), 500-507.

Elovainio, M., Kivimäki, M., Steen, N., \& Vahtera, J. (2004). Job decision latitude, organizational justice and health: Multilevel covariance structure analysis. Social Science \& Medicine, 58(9), 1659-1669.

Elovainio, M., Van Den Bos, K., Linna, A., Kivimäki, M., Ala-Mursula, L., Pentti, J., \& Vahtera, J. (2005). Combined effects of uncertainty and organizational justice on employee health: testing the uncertainty management model of fairness judgments among Finnish public sector employees. Social Science \& Medicine, 61(12), 2501-2512.

Falkenburg, K., \& Schyns, B. (2007). Work satisfaction, organizational commitment and withdrawal behaviours. Management Research News, 30(10), 708-723. http://dx.doi.org/10.1108/01409170710823430

Folger, R., \& Cropanzano, R. (1998). Organizational justice and human resource management. Thousand Oaks, CA: Sage.

Foong-ming, T. (2008). Linking Career development practices to turnover intention: The mediator of perceived organizational support. Journal of Business and Public Affairs, 2(1), 1-16.

Forrier, A., \& Sels, L. (2003). Flexibility, turnover and training. International Journal of Manpower, 24(2), 148-168. http://dx.doi.org/10.1108/01437720310475402

Foster, R. D. (2010). Resistance, justice, and commitment to change. Human Resource Development Quarterly, 21(1), 3-39. http://dx.doi.org/10.1002/hrdq.20035

Gentry, W. A., Kuhnert, K. W., Mondore, S. P., \& Page, E. E. (2007). The influence of supervisory-support climate and unemployment rate on part-time employee retention: A multilevel analysis. Journal of Management Development, 26(10), 1005-1022. http://dx.doi.org/10.1108/02621710710833432

George, J. M., Reed, T. F., Ballard, K. A., Colin, J., \& Fielding, J. (1993). Contact with AIDS patients as a source of work-related distress: Effects of organizational and social support. Academy of Management Journal, 36(1), 157-171. http://dx.doi.org/10.2307/256516

Gerhart, B. (1990). Voluntary turnover and alternative job opportunities. Journal of Applied Psychology, 75(5), 467-476. http://dx.doi.org/10.1037/0021-9010.75.5.467

Good, L. K., Page, T. J., \& Young, C. E. (1996). Assessing hierarchical differences in job-related attitudes and turnover among retail managers. Journal of the Academy of Marketing Science, 24(2), 148-156. http://dx.doi.org/10.1177/0092070396242005

Green, F., Machin, S. \& Wilkinson, D. (1996). An analysis of workplace training and skill shortages, research 
studies. London: Department for Education and Employment.

Greenberg, J. (1987). Reactions to procedural injustice in payment distributions: Do the means justify the ends? Journal of Applied Psychology, 72(1), 55-61. http://dx.doi.org/10.1037/0021-9010.72.1.55

Greenberg, J. (1990). Organizational justice: Yesterday, today, and tomorrow. Journal of Management, 16(2), 399-432. http://dx.doi.org/10.1177/014920639001600208

Greenberg, J. (2001). Setting the justice agenda: Seven unanswered questions about "what, why, and how". Journal of Vocational Behavior, 58(2), 210-219. http://dx.doi.org/10.1006/jvbe.2001.1792

Greenberg, J. (2006). Losing sleep over organizational injustice: Attenuating insomniac reactions to underpayment inequity with supervisory training in interactional justice. Journal of Applied Psychology, 91(1), 58-69. http://dx.doi.org/10.1037/0021-9010.91.1.58

Greenberg, J., \& Baron, R. A. (2008). Behavior in organizations (10th ed.). Pearson Prentice Hall.

Griffeth, R. W., Hom, P. W., \& Gaertner, S. (2000). A meta-analysis of antecedents and correlates of employee turnover: Update, moderator tests, and research implications for the next millennium. Journal of Management, 26(3), 463-488. http://dx.doi.org/10.1177/014920630002600305

Grover, S. L., \& Crooker, K. J. (1995). Who appreciates family-responsive human resource policies: The impact of family-friendly policies on the organizational attachment of parents and non-parents. Personnel Psychology, 48(2), 271-288.

Gupta, V., \& Srivastava, S. (2007). Employee Retention-Key to Success. Retrieved from http://http://www.hytechpro.com/newsletters/pdf/whitepaper-nov2007.pdf

Gustafson, C. M. (2002). Employee turnover: A study of private clubs in the USA. International Journal of Contemporary Hospitality Management, 14(3), 106-113. http://dx.doi.org/10.1108/09596110210424385

Harris, G. E., \& Cameron, J. E. (2005). Multiple dimensions of organizational identification and commitment as predictors of turnover intentions and psychological wellbeing. Canadian Journal of Behavioral Science, 37(3), 159-169. http://dx.doi.org/10.1037/h0087253

Hay, M. (2002). Strategies for survival in the war of talent. Career Development International, 7(1), 52-55. http://dx.doi.org/10.1108/13620430210414883

Higginbotham, J. S. (1997). The satisfaction equation. Research \& Development, 39(10), 1-9.

Hinkin, T. R., \& Tracey, J. B. (2000). The cost of turnover: Putting a price on the learning curve. The Cornell Hotel and Restaurant Administration Quarterly, 41(3), 14-21. http://dx.doi.org/10.1016/S0010-8804(00)80013-0

Hollenbeck, J. R., \& Williams, C. R. (1986). Turnover functionality versus turnover frequency: A note on work attitudes and organizational effectiveness. Journal of Applied Psychology, 71(4), 606-611. http://dx.doi.org/10.1037/0021-9010.71.4.606

Hubbell, A. P., \& Chory-Assad, R. M. (2005). Motivating factors: Perceptions of justice and their relationship with managerial and organizational trust. Communication Studies, 56(1), 47-70. http://dx.doi.org/10.1080/0008957042000332241

Huselid, M. A. (1995). The impact of human resource management practices on turnover, productivity, and corporate financial performance. Academy of Management Journal, 38(3), 635-672. http://dx.doi.org/10.2307/256741

Iqbal, H. K., Aziz, U., \& Tasawar, A. (2012). Impact of organizational justice on organizational citizenship behavior: An empirical evidence from Pakistan. World Applied Sciences Journal, 19(9), http://dx.doi.org/1348-1354. 10.5829/idosi.wasj.2012.19.09.750

Judge, T. A., Higgins, C. A., Thoresen, C. J., \& Barrick, M. R. (1999). The big five personality traits, general mental ability, and career success across the life span. Personnel Psychology, 52(3), 621-652.

Judge, T. A., Cable, D. M., Boudreau, J. W., \& Bretz Jr, R. D. (1994). An empirical investigation of the predictors of executive career success. CAHRS Working Paper Series, 233-272.

Karimi, A., Alipour, O., Pour, M. A., \& Azizi, B. (2013). Relationship between organizational justice and job satisfaction in ministry of sports and youth in Iran. International Journal of Sport Studies, 3(11), $1149-1156$. 
Khan, M. H., Hassan, R., Anwar, S., Babar, T. S., Babar, K. S., \& Khan, D. I. (2007). Patient satisfaction with nursing care. Rawal Medical Journal, 32(1), 28-30.

Kochanski, J., \& Ledford, G. (2001). "How To Keep Me"-Retaining Technical Professionals. Research-Technology Management, 44(3), 31-38.

Konovsky, M. A. (2000). Understanding procedural justice and its impact on business organizations. Journal of Management, 26(3), 489-511. http://dx.doi.org/10.1177/014920630002600306

Kool, M., \& Van Dierendonck, D. (2012). Servant leadership and commitment to change, the mediating role of justice and optimism. Journal of Organizational Change Management, 25(3), 422-433. http://dx.doi.org/10.1108/09534811211228139

Lambert, E. G., Hogan, N. L., \& Barton, S. M. (2001). The impact of job satisfaction on turnover intent: A test of a structural measurement model using a national sample of workers. The Social Science Journal, 38(2), 233-250. http://dx.doi.org/10.1016/S0362-3319(01)00110-0

Larrabee, J. H., Janney, M. A., Ostrow, C. L., Withrow, M. L., Hobbs, G. R., \& Burant, C. (2003). Predicting registered nurse job satisfaction and intent to leave. Journal of Nursing Administration, 33(5), 271-283. http://dx.doi.org/10.1097/00005110-200305000-00003

Lashley, C. (2000). Hospitality retail management: A unit manager's guide. New York, NY: Routledge.

Lashley, C., \& Chaplain, A. (1999). Labour turnover: Hidden problem-hidden costs. Hospitality Review, 1(1), 49-54.

Law, D. W. (2005). Interactive organizational commitment and hardiness in public accountants' turnover. Managerial Auditing Journal, 20(4), 383-393. http://dx.doi.org/10.1108/02686900510592061

Leventhal, G. S., Karuza, J., \& Fry, W. R. (1980). Beyond fairness: A theory of allocation preferences. Justice and Social Interaction, 3, 167-218.

Loi, R., Hang-Yue, N., \& Foley, S. (2006). Linking employees' justice perceptions to organizational commitment and intention to leave: The mediating role of perceived organizational support. Journal of Occupational and Organizational Psychology, 79(1), 101-120. http://dx.doi.org/10.1348/096317905X39657

Lynn, M. (2002). Turnover's relationships with sales, tips and service across restaurants in a chain. International Journal of Hospitality Management, 21(4), 443-447. http://dx.doi.org/10.1016/S0278-4319(02)00026-9

Maertz, C. P., Griffeth, R. W., Campbell, N. S., \& Allen, D. G. (2007). The effects of perceived organizational support and perceived supervisor support on employee turnover. Journal of Organizational Behavior, 28(8), 1059-1075. http://dx.doi.org/10.1002/job.472

Maertz, C. P., Mosley, D. C., \& Alford, B. L. (2002). Does organizational commitment fully mediate constituent commitment effects? A reassessment and clarification. Journal of Applied Social Psychology, 32(6), 1300-1313. http://dx.doi.org/10.1111/j.1559-1816.2002.tb01437.x

Malik, M. E., \& Naeem, B. (2011). Impact of perceived organizational justice on organizational commitment of faculty: Empirical evidence from Pakistan. Interdisciplinary Journal of Research in Business, 1(9), 92-98.

Martinez-Tur, V., Peiro, J. M., Ramos, J., \& Moliner, C. (2006). Justice Perceptions as Predictors of Customer Satisfaction: The Impact of Distributive, Procedural, and Interactional Justice. Journal of Applied Social Psychology, 36(1), 100-119. http://dx.doi.org/10.1111/j.0021-9029.2006.00005.x

Masaiti, G., \& Naluyele, P. N. (2011). Strategies to retain and motivate employees in Africa: Examining the case of the ministry of education in Zambia. African Journal of Political Science and International Relations, $5(8), 409-423$.

Matin, H. Z., Jandaghi, G., \& Ahmadi, F. (2010). A comprehensive model for identifying factors impacting on development of organizational citizenship behavior. African Journal of Business Management, 4(10), 1932-1945.

Meyer, J. P., Allen, N. J., \& Smith, C. A. (1993). Commitment to organizations and occupations: Extension and test of a three-component conceptualization. Journal of Applied Psychology, 78(4), 538-551. http://dx.doi.org/10.1037/0021-9010.78.4.538

Meyer, J. P., Stanley, D. J., Herscovitch, L., \& Topolnytsky, L. (2002). Affective, continuance, and normative commitment to the organization: A meta-analysis of antecedents, correlates, and consequences. Journal of Vocational Behavior, 61(1), 20-52. http://dx.doi.org/10.1006/jvbe.2001.1842 
Mobley, W. H. (1982). Employee turnover: Causes, consequences, and control. Philippines: Addison-Wesley Publishing.

Moorman, R. H. (1991). Relationship between organizational justice and organizational citizenship behaviors: Do fairness perceptions influence employee citizenship? Journal of Applied Psychology, 76(6), 845-855. http://dx.doi.org/10.1037/0021-9010.76.6.845

Moran, E. T., \& Volkwein, J. F. (1992). The cultural approach to the formation of organizational climate. Human Relations, 45(1), 19-47. http://dx.doi.org/10.1177/001872679204500102

Mowday, R. T., Porter, L. W., \& Steers, R. M. (1982). Employee-organization linkages: The psychology of commitment, absenteeism, and turnover. In P. Warr (Ed.), Organizational and Occupational Psychology. London: Academic Press Inc.

Mowday, R. T., Steers, R. M., \& Porter, L. W. (1979). The measurement of organizational commitment. Journal of Vocational Behavior, 14(2), 224-247.

Newstrom, J. W. (2007). Organizational behavior: Human behavior at work (12th ed.). New York, NY: McGraw-Hill/Irwin.

Nojani, M. I., Arjmandnia, A. A., Afrooz, G. A., \& Rajabi, M. (2012). The study on relationship between organizational justice and job satisfaction in teachers working in general, special and gifted education systems. Procedia-Social and Behavioral Sciences, 46, 2900-2905. http://dx.doi.org/10.1016/j.sbspro.2012.05.586

O'Connell, M., \& Kung, M. C. (2007). The cost of employee turnover. Industrial Management, 49(1), 14-19.

Paolillo, A., Platania, S., Magnano, P., \& Ramaci, T. (2015). Organizational Justice, Optimism and Commitment to Change. Procedia-Social and Behavioral Sciences, 191, 1697-1701. http://dx.doi.org/10.1016/j.sbspro.2015.04.479

Parry, J. (2008). Intention to leave the profession: Antecedents and role in nurse turnover. Journal of Advanced Nursing, 64(2), 157-67. http://dx.doi.org/10.1111/j.1365-2648.2008.04771.x

Pettman, B. O. (1975). External and personal determinants of labour turnover. Labour turnover and retention, Essex, Great Britain: Gower Press Limited, 31-50.

Price, J. L., \& Mueller, C. W. (1986). Absenteeism and turnover of hospital employees. JAI Press.

Qi, Y. T. (2007). Job opportunity, organizational commitment and turnover intention. China-USA Business Review, 6(2), 62-66.

Rafei-Dehkordi, F., Mohammadi, S., \& Yektayar, M. (2013). Relationship of organizational justice and organizational commitment of the staff in general directorate of youth and sports in Chahar Mahal Va Bakhtiari Province. European Journal of Experimental Biology, 3(3), 696-700.

Ramamoorthy, N., \& Flood, P. C. (2004). Gender and employee attitudes: The role of organizational justice $\begin{array}{llll}\text { perceptions. British Journal of } & \text { 247-258. }\end{array}$ http://dx.doi.org/10.1111/j.1467-8551.2004.00417.x

Rashid, M., Wineman, J., \& Zimring, C. (2009). Space, behavior, and environmental perception in open plan offices: a prospective study. Environment and Planning B: Planning and Design, 36(3) 432-449. http://dx.doi.org/10.1068/b33034

Rhoades, L., \& Eisenberger, R. (2002). Perceived organizational support: A review of the literature. Journal of Applied Psychology, 87(4), 698-714. http://dx.doi.org/10.1037/0021-9010.87.4.698

Rhoades, L., Eisenberger, R., \& Armeli, S. (2001). Affective commitment to the organization: The contribution of perceived organizational support. Journal of Applied Psychology, 86(5), 825-836. http://dx.doi.org/10.1037/0021-9010.86.5.825

Rust, R. T., Stewart, G. L., Miller, H., \& Pielack, D. (1996). The satisfaction and retention of frontline employees: A customer satisfaction measurement approach. International Journal of Service Industry Management, 7(5), 62-80. http://dx.doi.org/10.1108/09564239610149966

Schervish, P. G. (1983). The structural determinants of unemployment, vulnerability and power in market relations. New York: Academic Press.

Schyns, B., Van Veldhoven, M., \& Wood, S. (2009). Organizational climate, relative psychological climate and job satisfaction: The example of supportive leadership climate. Leadership \& Organization Development 
Journal, 30(7), 649-663. http://dx.doi.org/10.1108/01437730910991664

Settoon, R. P., Bennett, N., \& Liden, R. C. (1996). Social exchange in organizations: Perceived organizational support, leader-member exchange, and employee reciprocity. Journal of Applied Psychology, 81(3), 219-227. http://dx.doi.org/10.1037/0021-9010.81.3.219

Sousa-Poza, A., \& Sousa-Poza, A. A. (2007). The effect of job satisfaction on labor turnover by gender: An analysis for Switzerland. Journal of Socio-Economics, 36(6), 895-913. http://dx.doi.org/10.1016/j.socec.2007.01.022

Stinglhamber, F., \& Vandenberghe, C. (2003). Organizations and supervisors as sources of support and targets of commitment: A longitudinal study. Journal of Organizational Behavior, 24(3), 251-270. http://dx.doi.org/10.1002/job.192

Stone, P. W., Larson, E. L., Mooney-Kane, C., Smolowitz, J., Lin, S. X., \& Dick, A. W. (2006). Organizational climate and intensive care unit nurses' intention to leave. Critical Care Medicine, 34(7), 1907-1912. http://dx.doi.org/10.1097/01.CCM.0000218411.53557.29

Taheri, F., \& Soltani, E. (2013). The study of organizational justice effect on job satisfaction and organizational citizenship behavior (Case study: Organization of Roads and Urban Development of Golestan State). World of Sciences Journal, 1(15), 64-73.

Tai, T. W. C., \& Robinson, C. D. (1998). Reducing staff turnover: A case study of dialysis facilities. Health Care Management Review, 23(4), 21-42.

Thatcher, J. B., Stepnia, L. P., \& Boyle, R. J. (2003). Turnover of information technology workers: Examining empirically the influence of attitudes, job characteristics and external markets. Journal of Management Information Systems, 19(3), 231-261.

Terborg, J. R., \& Lee, T. W. (1984). A predictive study of organizational turnover rates. Academy of Management Journal, 27(4), 793-810. http://dx.doi.org/10.2307/255879

Tracey, J. B., \& Hinkin, T. R. (2008). Contextual factors and cost profiles associated with employee turnover. Cornell Hospitality Quarterly, 49(1), 12-27. http://dx.doi.org/10.1177/0010880407310191

Tyler, T. R., \& Blader, S. L. (2003). The group engagement model: Procedural justice, social identity, and cooperative behavior. Personality and Social Psychology Review, 7(4), 349-361. http://dx.doi.org/10.1207/S15327957PSPR0704_07

Walsh, K., \& Taylor, M. S. (2007). Developing in-house careers and retaining management talent what hospitality professionals want from their jobs. Cornell Hotel and Restaurant Administration Quarterly, 48(2), 163-182. http://dx.doi.org/10.1177/0010880407300521

Walters, G., \& Raybould, M. (2007). Burnout and perceived organizational support among front-line hospitality employees. Journal of Hospitality and Tourism Management, 14(2), 144-156.

Wanberg, C. R., \& Banas, J. T. (2000). Predictors and outcomes of openness to changes in a reorganizing workplace. Journal of Applied Psychology, 85(1), 132-142. http://dx.doi.org/10.1037/0021-9010.85.1.132

Wayne, S. J., Shore, L. M., \& Liden, R. C. (1997). Perceived organizational support and leader-member exchange: A social exchange perspective. Academy of Management Journal, 40(1), 82-111. http://dx.doi.org/10.2307/257021

Weil, P. A., \& Kimball, P. A. (1995). A model of voluntary turnover among hospital CEOs. Journal of Healthcare Management, 40(3), 362-385.

Wright, T. A., \& Bonett, D. G. (2007). Job satisfaction and psychological well-being as nonadditive predictors of workplace turnover. Journal of Management, 33(2), 141-160. http://dx.doi.org/10.1177/0149206306297582

Yoon, J., \& Lim, J. C. (1999). Organizational support in the workplace: The case of Korean hospital employees. Human Relations, 52(7), 923-945. http://dx.doi.org/10.1177/001872679905200704

Yoon, J., \& Thye, S. (2000). Supervisor support in the work place: Legitimacy and positive affectivity. The Journal of Social Psychology, 140(3), 295-316. http://dx.doi.org/10.1080/00224540009600472 


\section{Copyrights}

Copyright for this article is retained by the author(s), with first publication rights granted to the journal.

This is an open-access article distributed under the terms and conditions of the Creative Commons Attribution license (http://creativecommons.org/licenses/by/3.0/). 